\title{
Inheritance of sex in two ZZ pseudofemale lines of tilapia Oreochromis aureus
}

\author{
Damien Desprez ${ }^{\mathrm{a}, \mathrm{b}, \mathrm{c}, *}$, Charles Mélard ${ }^{\mathrm{c}}$, Marie Claude Hoareau ${ }^{\mathrm{a}}$, \\ Yohann Bellemène ${ }^{a}$, Pierre Bosc ${ }^{\mathrm{a}}$, Jean François Baroiller ${ }^{\mathrm{b}, \mathrm{d}}$ \\ a ARDA, Freshwater Aquaculture Center, BP 16, ZI Les Sables, 97427 Etang Salé, Reunion Island, France \\ ${ }^{\mathrm{b}}$ CIRAD EMVT, Aquaculture Research Unit, BP 5095, 34033 Montpellier cedex1, France \\ ${ }^{\mathrm{c}}$ University of Liège, CEFRA, 10 chemin de la Justice, 4500 Tihange, Liège, Belgium \\ ${ }^{\mathrm{d}}$ INRA, Laboratory of Fish Physiology, Avenue du Général Leclerc, 35042 Rennes Cedex, France
}

Received 2 July 2002; received in revised form 7 July 2002; accepted 10 October 2002

\begin{abstract}
This paper reports a study on the sex determination system of the blue tilapia, Oreochromis aureus. Investigations were carried out using a pseudofemale line in two populations of $O$. aureus, known as Egyptian Population (EP) and Israel Population (IP). In O. aureus, males are the homogametic sex $(\mathrm{ZZ} / \mathrm{ZW})$, and sex reversal of fry with estradiol results in the production of some functional sexreversed fish with a female phenotype and $\mathrm{ZZ}$ male genotype, known as pseudofemales or $\Delta$-females. Crosses between $\mathrm{ZZ}$ pseudofemales and $\mathrm{ZZ}$ males theoretically should provide monosex $\mathrm{ZZ}$ male progeny only. We have studied the sex ratios of progeny from $43 \mathrm{IP}\left(\mathrm{F}_{2}\right.$ to $\mathrm{F}_{3}$ generations $)$ and $51 \mathrm{EP}$ ( $F_{1}$ to $F_{5}$ generations), pair-matings between normal males and pseudofemales. In IP, the male percentage in progenies ranged between $83 \%$ to $100 \%$ in $\mathrm{F}_{2}$ and $66 \%$ to $100 \%$ in $\mathrm{F}_{3}$. In EP, male percentage was more constant, varying from $88 \%$ to $100 \%$ in $\mathrm{F}_{1}$, from $96 \%$ to $100 \%$ in $\mathrm{F}_{3}$ and from $97 \%$ to $100 \%$ in $\mathrm{F}_{5}$. In $\mathrm{EP}, \mathrm{F}_{2}$ and $\mathrm{F}_{4}$ pseudofemales produced only monosex male progeny. This apparent difference in sex ratio frequency distributions between the two $O$. aureus pseudofemale lines could be due to the selection of males. EP pseudofemales were mated with their siblings for $F_{2}$ and $F_{3}$ pseudofemales or with closely related males for $\mathrm{F}_{4}$ and $\mathrm{F}_{5}$ pseudofemales. Conversely, IP pseudofemales were crossed with nonrelated males originating from research center broodstock, resulting in a higher proportion of females in sex ratio of progenies from successive generations of pseudofemales. The role of inbreeding is discussed in the context of predominantly monofactorial sex chromosome determination system operating in this species, influenced by other factors (genetic and environmental). The present study also shows that it is possible to fix the male sex determining factors
\end{abstract}

* Corresponding author. ARDA, Freshwater Aquaculture Center, BP 16, ZI Les Sables, 97427 Etang Salé, Reunion Island, France. Tel.: +262 2-62-26-50-82; fax: +262 2-62-26-50-01.

E-mail address: desprez.arda@guetali.fr (D. Desprez). 
( $\mathrm{Z}$ sex chromosome and genetic factors) in a line of pseudofemales, producing a high percentage of male progeny in five successive generations.

(C) 2003 Elsevier Science B.V. All rights reserved.

Keywords: Oreochromis aureus; Sex determination; Sex chromosome; Pseudofemale; Monosex progeny

\section{Introduction}

Several different sex determination mechanisms have been observed in fish species, including hermaphroditism (Price, 1984; Chourrout, 1988), polygenic systems (Kallman, 1984), monofactorial sex determination systems (Chourrout, 1988) or environmental sex determination (Conover and Heins, 1987). In the genus Oreochromis, both male homogamety $(\mathrm{ZZ} / \mathrm{WZ})$ and female homogamety $(\mathrm{XX} / \mathrm{XY})$ have been proposed, based on experimental sex ratios from intraspecific crosses, involving normal or sex-reversed parents (Clemens and Inslee, 1968; Jalabert et al., 1974; Guerrero, 1975; Jensen and Shelton, 1979). Experimental results have demonstrated that monosex progeny were obtained when sex-reversed fish of the homogametic sex were mated with normal fish of the same sex genotype (Clemens and Inslee, 1968 in O. mossambicus; Yamamoto, 1969 in Oryzia latipes; Jalabert et al., 1974 in O. niloticus). In Oreochromis aureus, males are homogametic $(\mathrm{ZZ} / \mathrm{ZW})$, and sex reversal of fry with estradiol results in the production of some functional sex-reversed fish with a female phenotype and $\mathrm{ZZ}$ male genotype, known as pseudofemales (Jensen and Shelton, 1979; Mélard, 1995) or $\Delta$-females (Mair et al., 1987). First generation pseudofemales ( $F_{1}$ pseudofemales) can be identified by progeny testing: the cross between a $\mathrm{ZZ}$ pseudofemale and a normal $\mathrm{ZZ}$ male theoretically provides a monosex ZZ male progeny. Conversely, breeding ZW females gives $50 \% \mathrm{ZZ}$ males and $50 \% \mathrm{ZW}$ females. Sex-reversal treatment with estradiol, applied to monosex male progeny from $F_{1}$ pseudofemales, leads to second generation pseudofemales ( $F_{2}$ pseudofemales) (Mair et al., 1991b; Mélard, 1995), which do not need to be identified by progeny testing. This technique can be repeated through successive pseudofemale generations $\left(\mathrm{F}_{3}, \mathrm{~F}_{4} \ldots\right)$. If $O$. aureus utilised a monofactorial sex chromosome determination system, crosses of $\mathrm{ZZ}$ pseudofemales $\times$ ZZ males should give systematically ZZ male progenies only. Therefore, pseudofemale lines are of interest in studying the sex determination system, because deviations from expected (ठ/\%) sex ratio (1:0) in progenies can be easily identified. These deviations suggest the influence of an additional factor or factors (environmental or genetic) other than sex chromosomes also play a role in the sex determination in this species. Several authors have observed significant deviations from expected sex ratios in crosses involving O. aureus (Shelton et al., 1983; Mair et al., 1991b; Mélard, 1995), and hypotheses have been suggested to explain results, including a polygenic system of sex determination, epsitatic autosomal genes or environmental influence on sex differentiation (Majumdar and Mc Andrew, 1983; Lester et al., 1989; Mair et al., 1991b; Wohlfarth and Wedekind, 1991; Baroiller et al., 1995; Baroiller, 1996).

The present study was carried out using pseudofemales lines in two populations of $O$. aureus, known as Egyptian population (EP) and Israel population (IP). We have studied the sex ratio of progenies in $F_{1}$ to $F_{3}$ generations of the IP pseudofemale line and in $F_{1}$ to $F_{5}$ of 
the EP pseudofemale line. We have also analysed the influence of inbreeding on sex ratio variability, mating pseudofemales with closely related or nonrelated males. Inbreeding results were discussed in the context of a predominantly monofactorial sex determination system, influenced by additional factors (genetic and environmental). This study helps to further elucidate the sex determination system and the inheritance of the genetic sex determination in the genus Oreochromis and more especially in O. aureus. Understanding genetic sex determination systems in the genus Oreochromis contributes to the development of methods for controlling sex through genetic means, like the pseudofemale line in $O$. aureus to produce monosex male progeny.

\section{Materials and methods}

\subsection{Origin of fish}

The O. aureus Israel population (IP) originates from the Dor station in Israel. This population has been acclimated since 1979 in the experimental station of University of Liège (Belgium). Hulata et al. (1993) made it clear that the Dor station stock derived from the original founders collected in Lake Hula (North Israel) in about (1958). The O. aureus Egypt population (EP) originates from Lake Manzala in Egypt. This population was first transferred to the Ivory Coast (Institut des Savanes, Bouaké) and from there to ARDA-Freshwater Aquaculture center in Reunion Island (France, Indian Ocean) in 1995. This study was carried out in University of Liège (IP) and in ARDA-Freshwater Aquaculture Center (EP).

\subsection{Pseudofemale line production}

We describe below the different production stages of successive pseudofemale generations in the two populations, IP and EP. The method of $17 \alpha$-ethynylestradiol sex-reversal treatment and the progeny testing to identify the $\mathrm{F}_{1}$ pseudofemale were described in Mélard (1995). In this study, the pseudofemales were identified when sex ratio of progeny was significantly different $(P<0.05)$ from an expected sex ratio $\left(\delta^{\hat{O}} /+\right)$ of $1: 1$.

Israel population (IP) pseudofemale line: $\mathrm{F}_{1}$ pseudofemales were produced by sex reversal (100 to $200 \mathrm{mg}$ of $17 \alpha$-ethynylestradiol $\mathrm{kg}^{-1}$ of food for 40 days) of fry from three progenies of normal $O$. aureus. To obtain $\mathrm{F}_{2}$ pseudofemale broodstock, six progenies from five $F_{1}$ pseudofemales crossed with three males were submitted to a hormonal treatment of $150 \mathrm{mg}$ of $17 \alpha$-ethynylestradiol $\mathrm{kg}^{-1}$ of food for 40 days (Mélard, 1995). This treatment was applied to three progenies from two $F_{2}$ pseudofemales crossed with three males to produce $\mathrm{F}_{3}$ pseudofemale broodstock (Table 1).

Egypt population (EP) pseudofemale line: Three progenies of normal female EP were submitted to a sex-reversal treatment $\left(125 \mathrm{mg}\right.$ of $17 \alpha$-ethynylestradiol $\mathrm{kg}^{-1}$ of food for 40 days). Then, the same hormonal treatment was applied to two progenies from the same $F_{1}$ pseudofemale and to one progeny from an $F_{2}$ pseudofemale in order to produce $F_{2}$ and $F_{3}$ pseudofemale broodstock, respectively (Table 2). Fry from successive crossings of one $\mathrm{F}_{3}$ pseudofemale with two males were sex reversed $\left(125 \mathrm{mg}\right.$ of $17 \alpha$ ethynylestradiol $\mathrm{kg}^{-1}$ of food for 40 days) to produce $\mathrm{F}_{4}$ pseudofemale broodstock (Table 2). The same treatment 
Table 1

Proportion of males in progeny of repeat mated $\mathrm{F}_{2}$ and $\mathrm{F}_{3}$ pseudofemale $O$. aureus Israel Population (IP)

\begin{tabular}{|c|c|c|c|c|c|c|c|c|}
\hline Spawning number & & 1 & 2 & 3 & 4 & 5 & 6 & 7 \\
\hline $\begin{array}{l}\text { Pseudofemale } \\
\text { identification }\end{array}$ & Generation & Male \% & Male \% & Male \% & Male \% & Male \% & Male \% & Male $\%$ \\
\hline 1 & $\mathrm{~F}_{2}$ & 99 & 100 & 100 & 100 & 94 & 100 & \\
\hline 2 & $\mathrm{~F}_{2}$ & 100 & 100 & 89 & 95 & 100 & 100 & \\
\hline 3 & $\mathrm{~F}_{2}$ & 96 & 99 & 100 & 100 & 100 & 100 & 100 \\
\hline 4 & $\mathrm{~F}_{2}$ & 100 & 100 & 100 & 100 & 97 & 100 & \\
\hline 5 & $\mathrm{~F}_{2}$ & 98 & 100 & & & & & \\
\hline 6 & $\mathrm{~F}_{2}$ & 80 (a) & 83 (a) & 96 (b) & 93 (b) & & & \\
\hline 7 & $\mathrm{~F}_{2}$ & 86 (a) & & & & & & \\
\hline 8 & $\mathrm{~F}_{2}$ & 98 (a) & & & & & & \\
\hline 9 & $\mathrm{~F}_{3}$ & 70 & & & & & & \\
\hline 10 & $\mathrm{~F}_{3}$ & 98 (c) & 77 (d) & & & & & \\
\hline 11 & $\mathrm{~F}_{3}$ & 100 & & & & & & \\
\hline 12 & $\mathrm{~F}_{3}$ & 97 & & & & & & \\
\hline 13 & $\mathrm{~F}_{3}$ & 95 & & & & & & \\
\hline 14 & $\mathrm{~F}_{3}$ & 90 & & & & & & \\
\hline 15 & $\mathrm{~F}_{3}$ & 71 & & & & & & \\
\hline 16 & $\mathrm{~F}_{3}$ & 66 & & & & & & \\
\hline 17 & $\mathrm{~F}_{3}$ & 77 & & & & & & \\
\hline
\end{tabular}

$\mathrm{a}, \mathrm{b}, \mathrm{c}, \mathrm{d}$ : Male identification.

Bold results: progenies sex-reversed to produce $F_{3}$ pseudofemale generation.

was applied to two progenies from two $\mathrm{F}_{4}$ pseudofemales crossed with two males to produce $\mathrm{F}_{5}$ pseudofemale broodstock (Table 2).

To each $17 \alpha$-ethynylestradiol-treated group, we systematically added a control group that had not been submitted to hormonal treatment. After a period of 60 to 90 days or an average weight of $>3 \mathrm{~g}$, samples of 30 fish in treated groups and 100 fish in control groups were sexed by the aceto-carmine squash method (Guerrero and Shelton, 1974). At this stage of development, oocytes are easily identifiable in their auxocytosis or previtellogenesis stages and a typical lobular configuration is observed in the testes (Baroiller, 1996). Only the sex-reversed progenies of pseudofemales that produced $100 \%$ male in control group were retained for broodstock.

\subsection{Progeny testing}

IP $F_{1}$ to $F_{3}$ pseudofemales and EP $F_{1}$ to $F_{5}$ pseudofemales were progeny tested by crossing with related or nonrelated males. Some pseudofemales crossed several times $(n=2$ to 7) with the same or different normal males to check the sex ratio stability in the successive progeny. IP pseudofemales were crossed with largely unrelated IP males, taken from the $O$. aureus broodstock of the experimental station of University of Liège. Conversely, the EP males came from the control group of hormonal treatment. Thus, EP pseudofemales were mated with their siblings $\left(\mathrm{F}_{2}\right.$ and $\left.\mathrm{F}_{3}\right)$ or with closely related breeders $\left(\mathrm{F}_{4}\right.$ and $\left.\mathrm{F}_{5}\right)$. All tested males and pseudofemales were individually tagged with passive integrated transponder tags (Fish Eagle pit tag I.D. system). 
Table 2

Proportion of males in progeny of repeat mated $\mathrm{F}_{1}, \mathrm{~F}_{2}, \mathrm{~F}_{3}, \mathrm{~F}_{4}$ and $\mathrm{F}_{5}$ pseudofemale $O$. aureus Egypt Population (EP)

\begin{tabular}{|c|c|c|c|c|c|c|c|c|}
\hline Spawning number & & 1 & 2 & 3 & 4 & 5 & 6 & 7 \\
\hline $\begin{array}{l}\text { Pseudofemale } \\
\text { identification }\end{array}$ & Generation & Male $\%$ & Male $\%$ & Male $\%$ & Male $\%$ & Male $\%$ & Male $\%$ & Male $\%$ \\
\hline 18 & $\mathrm{~F}_{1}$ & 100 & 100 & 100 & & & & \\
\hline 19 & $\mathrm{~F}_{1}$ & 100 & 98 & 88 & & & & \\
\hline 20 & $\mathrm{~F}_{1}$ & 100 & & & & & & \\
\hline 21 & $\mathrm{~F}_{1}$ & 100 & & & & & & \\
\hline 22 & $\mathrm{~F}_{1}$ & 100 & & & & & & \\
\hline 23 & $\mathrm{~F}_{1}$ & 100 & & & & & & \\
\hline 24 & $\mathrm{~F}_{2}$ & $100(\mathrm{e})$ & & & & & & \\
\hline 25 & $\mathrm{~F}_{2}$ & $100(\mathrm{e})$ & & & & & & \\
\hline 26 & $\mathrm{~F}_{2}$ & $100(\mathrm{e})$ & & & & & & \\
\hline 27 & $\mathrm{~F}_{2}$ & $100(\mathrm{e})$ & & & & & & \\
\hline 28 & $\mathrm{~F}_{2}$ & $100(\mathrm{e})$ & & & & & & \\
\hline 29 & $\mathrm{~F}_{3}$ & $100(\mathrm{f})$ & & & & & & \\
\hline 30 & $\mathrm{~F}_{3}$ & $100(\mathrm{f})$ & $100(\mathrm{~g})$ & $100(\mathrm{~g})$ & $98(\mathrm{~g})$ & $100(\mathrm{~h})$ & $100(\mathrm{~h})$ & $100(\mathrm{~h})$ \\
\hline 31 & $\mathrm{~F}_{3}$ & 100 (f) & $100(\mathrm{~g})$ & $100(\mathrm{~h})$ & & & & \\
\hline 32 & $\mathrm{~F}_{3}$ & 100 (f) & $100(\mathrm{~g})$ & 99 (h) & $98(\mathrm{~h})$ & $97(\mathrm{~h})$ & & \\
\hline 33 & $\mathrm{~F}_{3}$ & $100(\mathrm{f})$ & $100(\mathrm{~g})$ & $100(\mathrm{~g})$ & & & & \\
\hline 34 & $\mathrm{~F}_{3}$ & $100(\mathrm{f})$ & $96(\mathrm{~g})$ & $100(\mathrm{~h})$ & & & & \\
\hline 35 & $\mathrm{~F}_{3}$ & 100 (f) & & & & & & \\
\hline 36 & $\mathrm{~F}_{4}$ & 100 (i) & 100 (i) & & & & & \\
\hline 37 & $\mathrm{~F}_{4}$ & $100(\mathrm{j})$ & $100(\mathrm{j})$ & & & & & \\
\hline 38 & $\mathrm{~F}_{5}$ & $100(\mathrm{k})$ & $100(\mathrm{k})$ & 100 (1) & & & & \\
\hline 39 & $\mathrm{~F}_{5}$ & 100 (1) & 100 (1) & & & & & \\
\hline 40 & $\mathrm{~F}_{5}$ & 97 (1) & 100 (1) & 100 (1) & & & & \\
\hline 41 & $\mathrm{~F}_{5}$ & 98 (1) & & & & & & \\
\hline
\end{tabular}

e, f, g, h, i, j, k, l: Male identification.

Bold results: progenies sex-reversed to produce next pseudofemale generation.

Israel population (IP) pseudofemale line: Pools of 10 to 15 pseudofemales and 1 male of the same generation were placed in spawning tanks $\left(4 \mathrm{~m}^{2} / 1.6 \mathrm{~m}^{3}\right)$ supplied with warm water $\left(25-27^{\circ} \mathrm{C}\right)$. The fertilised eggs were collected once a week and incubated in a small hatchery at a temperature of $27 \pm 1{ }^{\circ} \mathrm{C}$. After the yolk sac resorption, fry were reared in small aquaria (60 l) in a re-circulating system. Temperature minima and maxima for these experiments were 25.9 and $28.2{ }^{\circ} \mathrm{C}$, respectively. A progeny was identified by parental male and pseudofemale tag numbers. Some spawnings of $F_{2}$ and $F_{3}$ pseudofemales were also collected in spawning pools of 10 pseudofemales and 3 males (tanks of $4 \mathrm{~m}^{2} / 1.6 \mathrm{~m}^{3}$ supplied with warm water, $25-27^{\circ} \mathrm{C}$ ). In this case, the paternal origin of progenies was unknown.

Egypt population (EP) pseudofemale line: One male and five to six pseudofemales of the same generation were maintained in a 4001 thermo-regulated aquarium $\left(27 \pm 1{ }^{\circ} \mathrm{C}\right)$ in a re-circulating system. The reproductive status was checked twice a day by detection of female mouthbrooding behaviour. Mouthbrooding females were isolated in their respective aquaria and progenies were removed from the mouth of female 9-10 days after spawning. Each progeny was identified by male and female tag numbers and was reared in a small 
tank (100 1) within a re-circulating system. Temperature minima and maxima for these experiments were 26.5 and $30.1{ }^{\circ} \mathrm{C}$, respectively.

Fry were sexed as described above, and a sample of 100 fish from each progeny was analysed. The sex ratio of the pseudofemale progeny was compared to the theoretical sex ratio $(\widehat{\delta} /+)(1: 0 ; 1: 1$ or $3: 1)$ using a $2 \times 2$ contingency $\chi^{2}$ test.

\section{Results}

\subsection{Israel population (IP) pseudofemale line}

Results on $F_{1}$ pseudofemales were presented already in Mélard (1995). In brief, the $F_{1}$ pseudofemales $(n=22)$ produced percentage of males ranging from $80 \%$ to $100 \%$ and seven $F_{1}$ pseudofemales systematically produced monosex male progeny in successive crossings. Progeny sex ratios from repeated pair-matings were not significantly different in the successive crossings, except for five pseudofemales presenting heterogeneous results (maximum difference: $16.4 \%$ ).

In the present study, six and two pair-matings, respectively, in $\mathrm{F}_{2}$ and $\mathrm{F}_{3}$ pseudofemales were tested. Additional results (35 pair-matings) were also obtained from 13 pseudofemales $\left(\mathrm{F}_{2}\right.$ and $\left.\mathrm{F}_{3}\right)$, in which, the male parent was not identified (Table 1). $\mathrm{F}_{2}$ and $\mathrm{F}_{3}$ pseudofemales produced mean male percentages of $97.1 \pm 5.2 \%$ and $84.1 \pm 12.5 \%$ (Table 1 ), respectively.

The male percentage ranged between $80.0 \%$ and $100.0 \%$ in progenies from $\mathrm{F}_{2}$ pseudofemales, and $\mathrm{F}_{2}$ progeny sex ratios from $57.6 \%(n=19)$ pseudofemales crosses were 1:0. Crossing $\mathrm{F}_{2}$ pseudofemale " 6 ", the percentage of males in progeny involving male "b" (93 and 96\%) was significantly higher than with male "a" $(80 \%$ and $83 \%)\left(\chi^{2}\right.$ test, $P<0.05)$. Sex ratios from crosses of male "a" with three $\mathrm{F}_{2}$ pseudofemales produced three different sex ratios (Table 1), one not significantly different from a 3:1 (pseudofemale $6, \chi^{2}=0.72, P>0.05$ ), one significantly different from $3: 1$ and $1: 0$ (pseudofemale $7 ; \chi^{2}=$ 3.85 and $15.05, P<0.05$ ), and the last one not significantly different from 1:0 (pseudofemale $\left.8, \chi^{2}=2.02, P>0.05\right)$.

Nine $\mathrm{F}_{3}$ pseudofemales were progeny tested. The results are shown in Table 1. Only the pseudofemale " 11 " gave monosex male progeny. The percentage of males in the other $\mathrm{F}_{3}$ pseudofemale progenies ranged from $66 \%$ to $98 \% . \mathrm{F}_{3}$ pseudofemale " 10 " produced successively $98 \%$ and $77 \%$ males $\left(\chi^{2}=20.16, P<0.05\right)$ with males "c" and "d", respectively (Table 1 ).

\subsection{Egypt population (EP) pseudofemale line}

Fifty one pair-matings were tested, involving $\mathrm{F}_{1}$ to $\mathrm{F}_{5}$ pseudofemales. The five successive generations produced mean sex ratios of $98.6 \pm 3.6 \%, 100 \%, 99.5 \pm 1.1 \%, 100 \%$ and $99.4 \pm 1.1 \%$ of males. The mean sex ratio in EP $F_{3}$ pseudofemale $(99.5 \pm 1.1 \%$ of males) was significantly higher than in IP $F_{3}$ pseudofemale $(84.2 \pm 12.5 \%)$ (Mann and Whitney test, $U=27.5 ; n=10 ; m=23 ; P<0.05)$. Opposite of that, the other possible comparisons of sex ratio between the pseudofemale generations were not significantly different (Mann and Whitney test, $P>0.05$ ). 
The percentages of male monosex (1:0) progeny from $\mathrm{F}_{1}, \mathrm{~F}_{2}, \mathrm{~F}_{3}, \mathrm{~F}_{4}$ and $\mathrm{F}_{5}$ EP pseudofemales were respectively $80.0 \%(n=10$ progeny tested), $100.0 \%(n=5), 78.3 \%(n=23)$, $100.0 \%(n=4)$ and $77.8 \%(n=9)$ (Table 2). Sex ratios in progeny from $\mathrm{F}_{1}$ to $\mathrm{F}_{5}$ pseudofemales were not significantly different from a sex ratio of 1:0, except when crossing $\mathrm{F}_{1}$ pseudofemale "19" $\left(88 \%\right.$ males, $\left.\chi^{2}=12.76, P<0.05\right)$ and $\mathrm{F}_{3}$ pseudofemale "34" with male "g" $\left(96 \%\right.$ males, $\left.\chi^{2}=4.08, P<0.05\right)$ (Table 2$)$. There was no significant difference in progeny sex ratios from repeated crosses of pair-matings, except with $F_{1}$ pseudofemale " 19 " and $\mathrm{F}_{3}$ pseudofemale " 34 " ( $\chi^{2}$ test, $\left.P<0.05\right)$ (Table 2).

\section{Discussion}

The present study show that it is possible to obtain high male progeny in successive generations of pseudofemales in $O$. aureus by progeny testing and hormonal sex reversal. The monofactorial sex determination system with two sex chromosomes $(\mathrm{Z}, \mathrm{W})$ in $O$. aureus is supported by our results on the analysis of progeny sex ratios from pseudofemales. Since deviations from all-male sex ratios were obtained in progeny from $\mathrm{F}_{2}$ and $\mathrm{F}_{3} \mathrm{IP}$ pseudofemales. Similar deviations from monosex ratios have also obtained in O. aureus (Mair et al., 1987, 1991b) and in O. niloticus (Mair et al., 1991a, 1997; Pham et al., 1999). To explain these results in $O$. aureus, which are not consistent with a monofactorial sex determination system, Mair et al. (1991b) proposed a more complex system, based on the existence of an autosomal recessive gene $(\mathrm{F}, \mathrm{f})$ epistatic to the main sex chromosomes $(\mathrm{Z}, \mathrm{W})$ in $O$. aureus. The combination of a homozygous autosomal recessive allele with either pair of sex chromosomes (ZZ or WZ) would produce a phenotypic female (i.e. genotype ZZ/ff gives a phenotypic female). This hypothesis is in part in accordance with our results, and could explain the deviating sex ratios in $\mathrm{F}_{2}$ and $\mathrm{F}_{3}$ pseudofemale progeny of IP which were not significantly different from 3:1. As suggested by Wohlfarth and Wedekind (1991) in $O$. niloticus, the variability of sex ratio in relation to monofactorial sex determination system results from autosomal loci influencing sex determination. The results on IP $\mathrm{F}_{2}$ pseudofemale " 6 " also suggest the influence on sex determination of an additional genetic factors other than sex chromosomes (Table 1). These genetic factors would interfere with sex differentiation regulated by the expression of genes on the sex chromosomes. Thus, the sex determination in Oreochromis will not depend only on sex chromosomes, but will equally be influenced by one or more other genetic factors. However, the present study also shows that it is possible to fix male sex determining factors ( $\mathrm{Z}$ sex chromosome and genetic factor(s)) in a line of $O$. aureus pseudofemale.

In the present study, only the sex-reversed progeny of pseudofemales that produced $100 \%$ male in the control group was retained for broodstock, effectively representing selection against sex modifying factors. According to the results, this selection of pseudofemales may have been more effective in the EP pseudofemale line than in the IP, because the mean sex ratio in $\mathrm{EP} \mathrm{F}_{3}$ pseudofemale $(99.5 \pm 1.1 \%)$ was higher than in IP $\mathrm{F}_{3}$ pseudofemale $(84.2 \pm 12.5 \%)$. This difference could be due to the selection of males, since EP pseudofemales were mated with their siblings (pseudofemales $F_{2}$ and $F_{3}$ ) or with closely related breeders (pseudofemales $\mathrm{F}_{4}$ and $\mathrm{F}_{5}$ ), whereas IP pseudofemales were crossed with nonrelated males originating from unselected broodstock. A high degree of inbreeding in 
the EP line may have furthered selection of autosomal male determining factors. Conversely, nonrelated males, crossed with IP pseudofemales, could have carried female determining factors. The balance of these autosomal sex factors could influence sex chromosome expression and their effects could have increased in successive generations of pseudofemales, explaining the decrease in male percentage in progeny of the $\mathrm{F}_{2}$ and $\mathrm{F}_{3}$ IP pseudofemales. Complex models of sex determination, as proposed by Mair et al. (1991b), cannot be applied to all species of genus Oreochromis (Mair et al., 1991a,b; Wohlfarth and Wedekind, 1991) and to all populations of a species (Shelton et al., 1983; Mair et al., 1991b; the present study). Furthermore, there are inherent differences in sex ratio variability between populations in O. niloticus (Shelton et al., 1983; Mair et al., 1991a; Pham et al., 1999) and in O. aureus (Shelton et al., 1983; Mair et al., 1991b). This inherent difference between populations could explain the sex ratio variability obtained in EP and IP lines. These results also suggest that autosomal sex factors would be specific to each species or to each population. Crossing-over and recombination of sex determining genes also could account for these unpredicted sex ratios (Avtalion and Don, 1990; Mair et al., 1991a,b; Müller-Belecke and Hörstgen-Schwark, 1995).

A number of studies have demonstrated that high temperatures $\left(34-36{ }^{\circ} \mathrm{C}\right)$ strongly skewed the sex ratio in favour of male (Lester et al., 1989; Baroiller et al., 1995; Abucay et al., 1999 in O. niloticus; Desprez and Mélard, 1998 in O. aureus) and high proportions of males can be produced in O. aureus (95-100\%) (Desprez and Mélard, 1998) and $O$. niloticus $(98-100 \%)$ (Baroiller and Clota, 1997). However, it is unlikely that temperature was involved in the present study because during the rearing of progenies, the temperature has never above $30.0{ }^{\circ} \mathrm{C}$ in EP and $28.5^{\circ} \mathrm{C}$ in IP which was below the minimum level (34 ${ }^{\circ} \mathrm{C}$ ) for temperature influence, determined by Baroiller et al. (1995) in O. niloticus. However, the effects of other environmental factors $(\mathrm{pH}$, day length, salinity...) on sex determination cannot be discounted. Low $\mathrm{pH}$ has also been observed to affect sex ratio in Cichlids and Poeciliids (Rubin, 1985), e.g. in Apistogramma (Teleostei, Cichlidae) (Römer and Beisenherz, 1996). In O. niloticus, varying levels of salinity did not significantly affect sex ratio but brought about a slight difference (Abucay et al., 1999). The effects of some environmental factors could result more in low-marked variation, than temperature, and explain either these slight variations of sex ratio or differences in repeated crossings in $O$. aureus pseudofemale lines.

Although temperature and other factors influence sex determination in Oreochromis, the conclusion must be that sex in $O$. aureus is mainly determined by a monofactorial sex chromosome determination system with an influence of other genetic (autosomal factors, crossing-over). The present study shows that it is possible to obtain a line of pseudofemales, producing a high percentage of male progeny in five successive generations. Several studies showed that genetic approach can be used to produce progeny with a high percentage of males: ZZ pseudofemale line in O. aureus (Jensen and Shelton, 1979; Lahav, 1993; Desprez et al., 1995) and YY super male line in O. niloticus (Scott et al., 1989; Mair et al., 1997). The genetic approach avoids the hormonal sex-reversal treatment on a mass scale and the problem of androgen residues in market-sized fish. The present study suggests that the application of a genetic process to aquaculture requires strict selection of both sexes (male and female) and not just of one sex (super-male YY or pseudofemale ZZ). The existence of a complex sex determination mechanism involving sex chromosomes and other genetic 
factors in Oreochromis species justifies that very selection. Although further studies on sex determination will be necessary to optimise the selection.

\section{Acknowledgements}

The authors thank Dr. G. Hulata and the anonymous referees for their comments and suggestions that have greatly improved the quality of manuscript. This research was supported by Electrabel, Piscimeuse, a special research fund of the University of Liège (Belgium) and funds from Tilapia Research-Development Programme in Reunion Island (Conseil Régional de La Réunion, France). The authors gratefully acknowledge M.P. Banaix for reviewing the English constructions of the article.

\section{References}

Abucay, J.S., Mair, G.C., Skibinski, D.O.F., Beardmore, J.A., 1999. Environmental sex determination: the effect of temperature and salinity on sex ratio in Oreochromis niloticus. Aquaculture 173, 219-234.

Avtalion, R.R., Don, J., 1990. Sex-determining genes in tilapia: a model of genetic recombination emerging from sex-ratio results of three generations of diploid gynogenetic Oreochromis aureus. J. Fish Biol. 37, $167-173$.

Baroiller, J.F., 1996. Significant proportions of unexpected males in progenies from single pair matings with sibling sex-reversed males of Oreochromis niloticus. In: Pullin, R.S.V., Lazard, J., Legendre, M., Amon Kothias, J.B., Pauly, D. (Eds.), Proceedings of the Third Symposium on Tilapia in Aquaculture. ICLARM Conf. Proc., vol. 41, pp. 229-237.

Baroiller, J.F., Clota, F., 1997. Interactions between temperature effects and genotype on Oreochromis niloticus sex determination. J. Exp. Zool. 281, 507 (Abstract).

Baroiller, J.F., Chourrout, D., Fostier, A., Jalabert, B., 1995. Temperature and sex chromosomes govern sex-ratios of the mouthbrooding cichlid fish Oreochromis niloticus. J. Exp. Zool. 273, 216-223.

Chourrout, D., 1988. Revue sur le déterminisme génétique du sexe des poissons téléostéens. Bull. Soc. Zool. Fr. 113, 123-144 (in French with English abstract).

Clemens, H.P., Inslee, T., 1968. The production of unisexual broods by Tilapia mossambica sex-reversed with methyltestosterone. Trans. Am. Fish. Soc. 97 (1), 18-21.

Conover, D.O., Heins, S.W., 1987. Adaptative variation in environmental and genetic sex determination in a fish. Nature 326, 496-498.

Desprez, D., Mélard, C., 1998. Effect of ambient temperature on sex determinism in the blue tilapia Oreochromis aureus. Aquaculture 162, 79-84.

Desprez, D., Mélard, C., Philippart, J.C., 1995. Production of a high percentage of male offspring with $17 \alpha-$ ethynylestradiol sex-reversed Oreochromis aureus: II. Comparative reproductive biology of females and $\mathrm{F}_{2}$ pseudofemales and large-scale production of male progeny. Aquaculture 130, 35-41.

Guerrero, R.D., 1975. Use of androgens for the production of all male Tilapia aurea (Steindachner). Trans. Am. Fish. Soc. 104, 342-348.

Guerrero, R.D., Shelton, W.L., 1974. An aceto-carmine squash method for sexing juvenile fishes. Prog. FishCult. 36, 56.

Hulata, G., Wohlfarth, G.W., Karplus, I., Schroder, G.L., Harpaz, S., Halevy, A., Rothbard, S., Cohen, S., Israel, I., Kavessa, M., 1993. Evaluation of Oreochromis niloticus $\times$ Oreochromis aureus hybrid progeny of different geographical isolates, reared under varying management regimes. Aquaculture 115, 253-271.

Jalabert, B., Moreau, J., Planquette, P., Billard, R., 1974. Déterminisme du sexe chez Tilapia macrochir et Tilapia nilotica: action de la methyltestostérone dans l'alimentation des alevins sur la différenciation sexuelle; proportion des sexes dans la descendance des mâles "inversés". Ann. Biol. Anim. Biochim. Biophys. 14 (4-B), 729-739 (in French with English abstract). 
Jensen, G.L., Shelton, W.L., 1979. Effects of estrogens on Tilapia aurea: implications for production of monosex genetic male tilapia. Aquaculture 16, 233-242.

Kallman, K.D., 1984. A new look at sex determination in poeciliid fishes. In: Turner, B.J. (Ed.), Evolutionary Genetics of Fishes. Plenum, New York.

Lahav, E., 1993. Use of sex-reversed females to produce all-male tilapia (Oreochromis aureus) fry. Isr. J. Aquac.Bamidgeh 45, 131-136.

Lester, L.J., Lawson, K.S., Abella, T.A., Palada, M.S., 1989. Estimated heritability of sex-ratio and sexual dimorphism in tilapia. Aquac. Fish. Manage. 20, 369-380.

Mair, G.C., Penman, D.J., Scott, A., Skibinski, D.O.F., Beardmore, J.A., 1987. Hormonal sex-reversal and the mechanism of sex determination in Oreochromis. In: Tiews, K. (Ed.), Proceedings of Selection, Hybridisation and Genetic Engineering in Aquaculture, 27-30 May 1986, Bordeaux, France, Vol. 2, Berlin 1987, pp. 301-312.

Mair, G.C., Scott, A.G., Penman, D.J., Skibinski, D.O.F., Beardmore, J.A., 1991a. Sex determination in the genus Oreochromis: 1. Sex reversal, gynogenesis and triploidy in O. niloticus (L). Theor. Appl. Genet. 82, $144-152$.

Mair, G.C., Scott, A.G., Penman, D.J., Skibinski, D.O.F., Beardmore, J.A., 1991b. Sex determination in the genus Oreochromis: 2. Sex reversal, hybridisation, gynogenesis and triploidy in $O$. aureus Steindachner. Theor. Appl. Genet. 82, 153-160.

Mair, G.C., Abucay, J.S., Skibinski, D.O.F., Beardmore, J.A., 1997. Genetic manipulation of sex ratio for the large scale production of all-male tilapia, Oreochromis niloticus. Can. J. Fish. Aquat. Sci. 54, 396-404.

Majumdar, K.C., Mc Andrew, B.J., 1983. Sex ratio from interspecific crosses within the tilapias. In: Fishelson, L., Yaron, Z. (Eds.), Proceedings of the First International Symposium on Tilapia in Aquaculture. Tel Aviv University, Tel Aviv, pp. 261-269.

Mélard, C., 1995. Production of a high percentage of male offspring with $17 \alpha$-ethynylestradiol sex reversed Oreochromis aureus: I. Estrogen sex reversal and production of $\mathrm{F}_{2}$ pseudofemales. Aquaculture 130, $25-34$.

Müller-Belecke, A., Hörstgen-Schwark, G., 1995. Sex determination in tilapia (Oreochromis niloticus) sex ratios in homozygous gynogenetic progeny and their offspring. Aquaculture 137, 57-65.

Pham, A.T., Mair, G.C., Little, D.C., Beardmore, J.A., 1999. Sex determination and the feasibility of genetically male tilapia production in the Thai-Chitralada strain of Oreochromis niloticus. Aquaculture 173, 257-269.

Price, D.J., 1984. Genetics of sex-determination in fishes - a brief review. In: Potts, G.W., Wooton, R.J. (Eds.), Fish Reproduction: Strategies and Tactics. Academic Press, New York, pp. 77-89.

Römer, U., Beisenherz, W., 1996. Environmental determination of sex in Apogramma (Cichlidae) and two other freshwater (Teleostei). J. Fish Biol. 48, 714-725.

Rubin, D.A., 1985. Effect of $\mathrm{pH}$ on sex ratio in Cichlids and a poeciliid (Teleostei). Copeia 1, 233-235.

Scott, A.G., Penman, D.J., Beardmore, J.A., Skibinski, D.O.F., 1989. The YY supermale in Oreochromis niloticus (L.) and its potential in aquaculture. Aquaculture 78, 237-251.

Shelton, W.L., Meriwether, F.H., Kenneth, J.S., Calhoun, E.W., 1983. Progeny sex-ratio from intraspecific pair spawning of Tilapia aurea and Tilapia nilotica. In: Fishelson, L., Yaron, Z. (Eds.), Proceeding of the First International Symposium on Tilapia in Aquaculture. Tel Aviv University, Tel Aviv, pp. 270-280.

Wohlfarth, G.W., Wedekind, H., 1991. The heredity of sex determination in tilapias. Aquaculture 92, $143-156$.

Yamamoto, T., 1969. Sex differentiation. In: Hoar, W.S., Randall, D.J. (Eds.), Fish Physiology, vol. III. Academic Press, New York, pp. 117-175. 